\title{
Systemic Epstein-Barr Virus-Positive T-cell Lymphoproliferative Disease of Childhood Presenting as Hemophagocytic Lymphohistiocytosis with Chromosomal Abnormalities
}

Naery Yang ${ }^{1}$, Wha Soon Chung ${ }^{1}$, Yeung Chul Mun $^{2}$, and Jungwon $\operatorname{Huh}^{1}$

Departments of ${ }^{1}$ Laboratory Medicine and ${ }^{2}$ Internal Medicine, Ewha Womans University Mokdong Hospital, Ewha Womans University School of Medicine, Seoul, Korea

Corresponding author: Jungwon Huh Department of Laboratory Medicine, Ewha Womans University Mokdong Hospital, Ewha Womans University School of Medicine, 1071 Anyangcheonro, Yangcheon-gu, Seoul 158-710, Korea

Tel: +82-2-2650-5320

Fax: +82-2-2650-5091

E-mail: JungWonH@ewha.ac.kr
Epstein-Barr virus (EBV)-positive T-cell lymphoproliferative disease (EBV+ T-cell LPD) is characterized by a clonal proliferation of T-cells, which may trigger hemophagocytic lymphohistiocytosis (HLH). Chromosomal abnormalities in patients with HLH are usually found in association with underlying malignancies. We report here a case of systemic EBV+ T-cell LPD of childhood initially presenting with HLH. A 19-year-old man was admitted to the hospital with a 2-week history of fever. Laboratory data revealed pancytopenia, hypertriglyceridemia, high ferritin levels, and abnormalities in liver function tests. EBV infection was confirmed by serologic tests and real-time polymerase chain reaction. Examination of the bone marrow showed histiocytic hyperplasia and hemophagocytosis. Further investigation revealed atypical lymphoid cells expressing EBV-encoded RNA, CD3, CD4, and CD8. A chromosomal analysis displayed a complex karyotype. Despite intensive treatment, the patient died 15 days after initial presentation. In conclusion, systemic EBV+ T-cell LPD of childhood presenting with HLH and chromosomal abnormalities may progress rapidly and be fatal. Therefore, a diagnostic workup for chromosomal aberration is essential. (J Lab Med Qual Assur 2014;36:210-215)

Key Words : Epstein-Barr virus infections, T-cell lymphoproliferative disease, Chromosomal analysis, Chromosome aberrations, Hemophagocytic lymphohistiocytosis

Received November 10, 2014, Revision received November 26, 2014, Accepted December 3, 2014

\section{INTRODUCTION}

Epstein-Barr virus (EBV)-positive T-cell lymphoproliferative disease (EBV+T-cell LPD) is characterized by a clonal proliferation of EBV-infected T-cells [1]. The disease entity encompasses a heterogeneous group of disorders ranging from indolent to aggressive diseases, which occur predominantly in Asian populations and in Native Americans from central and South America [2]. A clonal expansion of EBV+T-cells produces inflammatory cytokines, which may induce the activation of macrophages, leading to hemophagocytic lymphohistiocytosis (HLH). In one study, 36\% of patients with $\mathrm{EBV}+\mathrm{T} /$ natural killer (NK)-cell LPD showed HLH at the 
time of diagnosis [3].

Clonal chromosomal abnormalities in patients with HLH are usually associated with underlying malignancies, whereas infection or autoimmune disease associated HLH is usually not accompanied by chromosomal abnormalities. Clonal EBV + HLH is classified as systemic EBV $+\mathrm{T} / \mathrm{NK}$-cell LPD of childhood, according to the 2008 WHO classification [4]. Systemic EBV+T/NK-cell LPD of childhood is a life-threatening illness in children and young adults. It is characterized by a clonal proliferation of EBV-infected T-cells with an activated cytotoxic phenotype [4]. Here, we report a case of systemic EBV+ T-cell LPD of childhood which presented with fatal HLH with chromosomal abnormalities.

\section{CASE REPORT}

A previously healthy 19-year-old man with fever and a cough for two weeks was transferred from a local hospital. Hepatosplenomegaly was noted on abdominal computed tomography scans. Peripheral blood examination revealed the following: white blood cell count, $0.4 \times 10^{9} / \mathrm{L}$ (consisting of 39\% segmented neutrophils, $18 \%$ band neutrophils, 37\% lymphocytes, 3\% monocytes, and 3\% atypical lymphocytes); hemoglobin, $101 \mathrm{~g} / \mathrm{L}$; and platelets $62 \times 10^{9} /$ $\mathrm{L}$. The patient was found to be coagulopathic with prothrombin time of 15.7 seconds (reference range, 10.2 to
13.1 seconds), activated partial thromboplastin time of 48.8 seconds (reference range, 20.6 to 31.1 seconds), fibrinogen $148 \mathrm{mg} / \mathrm{dL}$, fibrin degradation products $35.9 \mu \mathrm{g} /$ $\mathrm{mL}$, and D-dimer $8.91 \mathrm{mg} / \mathrm{L}$. The biochemical profile initially indicated mild renal impairment: sodium $126 \mathrm{mEq} / \mathrm{L}$, blood urea nitrogen $21 \mathrm{mg} / \mathrm{dL}$, and creatinine $1.27 \mathrm{mg} /$ $\mathrm{dL}$. However, the renal function quickly deteriorated over the following days with blood urea nitrogen and creatinine levels increasing to $125 \mathrm{mg} / \mathrm{dL}$ and $5.98 \mathrm{mg} / \mathrm{dL}$, respectively, on hospital day 6 . Liver function tests were abnormal with alanine transaminase 299 IU/L, alanine transaminase $256 \mathrm{IU} / \mathrm{L}$, gamma-glutamyl transpeptidase $194 \mathrm{IU} / \mathrm{L}$, and total bilirubin $2.9 \mathrm{mg} / \mathrm{dL}$. The initial serum ferritin level was $25,382 \mathrm{ng} / \mathrm{mL}$ (reference range, 30 to $400 \mathrm{ng} / \mathrm{mL}$ ), and within a week of admission, the values increased strikingly to $>100,000 \mathrm{ng} / \mathrm{mL}$. Other laboratory results included: triglycerides $411 \mathrm{mg} / \mathrm{dL}$, lactate dehydrogenase 1,804 IU/L, beta-2 microglobulin $14.7 \mathrm{mg} / \mathrm{L}$, total protein $4.6 \mathrm{~g} / \mathrm{dL}$, and albumin $2.7 \mathrm{~g} / \mathrm{dL}$. The patient fulfilled the diagnostic criteria for HLH [5]. EBV viral capsid antigen IgG and EBV nuclear antigen IgG were positive but EBV viral capsid antigen IgM was negative. A quantitative real-time polymerase chain reaction assay for EBV detected 283,000 copies/mL whole blood. Other viral markers were negative (hepatitis B surface antigen, antiHIV antibody, anti-hepatitis C virus antibody, anti-HAV IgM, anti-HSV IgM, anti-varicella zoster IgM, and anti-
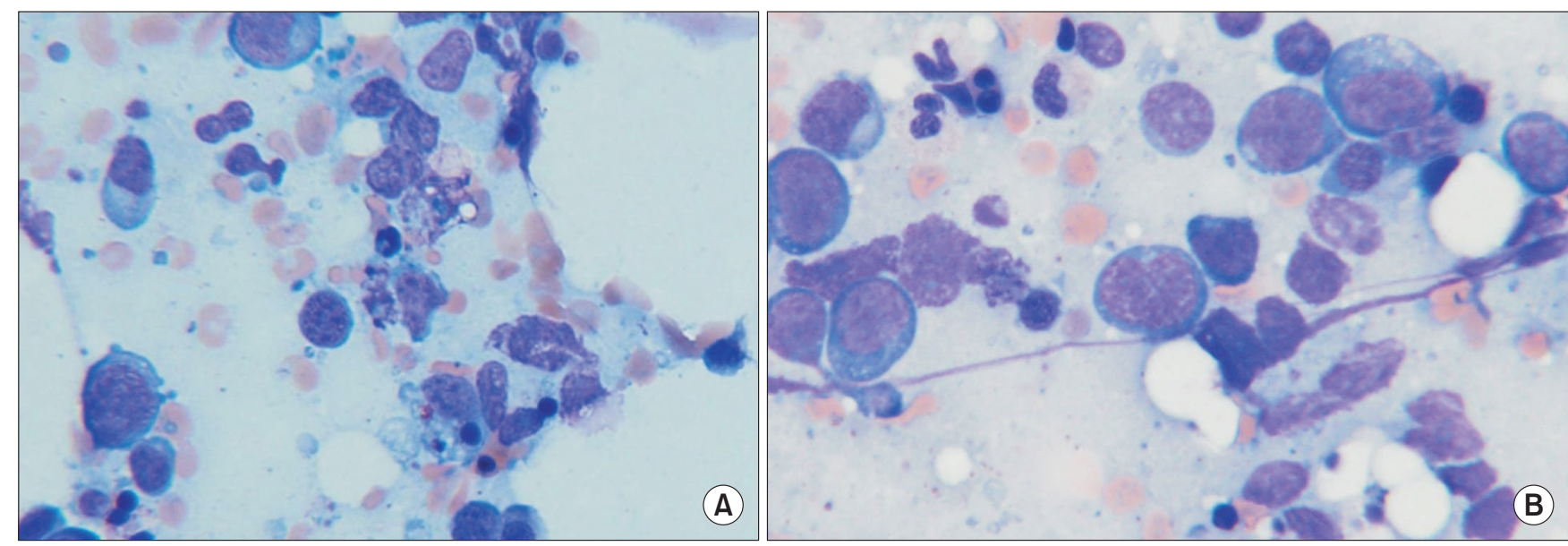

Fig. 1. (A) The bone marrow aspirate showing (A) increased number of histiocytes with active hemophagocytosis and (B) the atypical lymphoid cells (Wright-Giemsa stain, $\times 400$ ). 
CMV IgM). Initial blood and urine cultures did not show any growth of pathologic organisms.

The bone marrow was hypercellular ( $85 \%$ on biopsy) with normal maturation of erythroid cells. Megakaryocytes were adequate in number while myeloid lineage cells were decreased. Increased numbers of histiocytes (28\% of nucleated cells) with hemophagocytic activity were prominent. Further investigation revealed intermediate to large sized atypical lymphoid cells, accounting for more than $18 \%$ of nucleated cells (Fig. 1).

Cytochemical stains for myeloperoxidase, Sudan black B, nonspecific esterase, and specific esterase were negative in the atypical lymphoid cells. The immunophenotype of the atypical lymphoid cells was positive for CD3, CD5, and CD7 and negative for CD19, CD20, and CD22. On immunohistochemistry, these atypical lymphoid cells were positive for EBV-encoded RNA. The cells expressed CD3,
CD4, and CD8 with CD4 predominance, but they were negative for CD20, CD30, CD34, and CD56. Numerous histiocytes were highlighted by CD68 staining (Fig. 2).

Karyotypic analysis on the bone marrow aspirate demonstrated a complex karyotype in 6 out of 20 metaphase cells examined, suggesting the presence of clonal neoplasm. The karyotype was 47,XY,+del(X) (q24),?del(6) (q13q21), add (9) (p24), add(14) (p10), +19, der(19)t(1;19) (q24;p13.3),-22[cp6]/46,XY[14] (Fig. 3).

The patient received prednisone and broad-spectrum antibiotic therapy starting at admission. Cyclosporine was added to the regimen from hospital day 3. Despite intensive treatment and blood transfusion, his pancytopenia persisted, and he deteriorated rapidly with renal failure, pneumonia, and sepsis. He succumbed to septic shock 15 days after initial presentation.

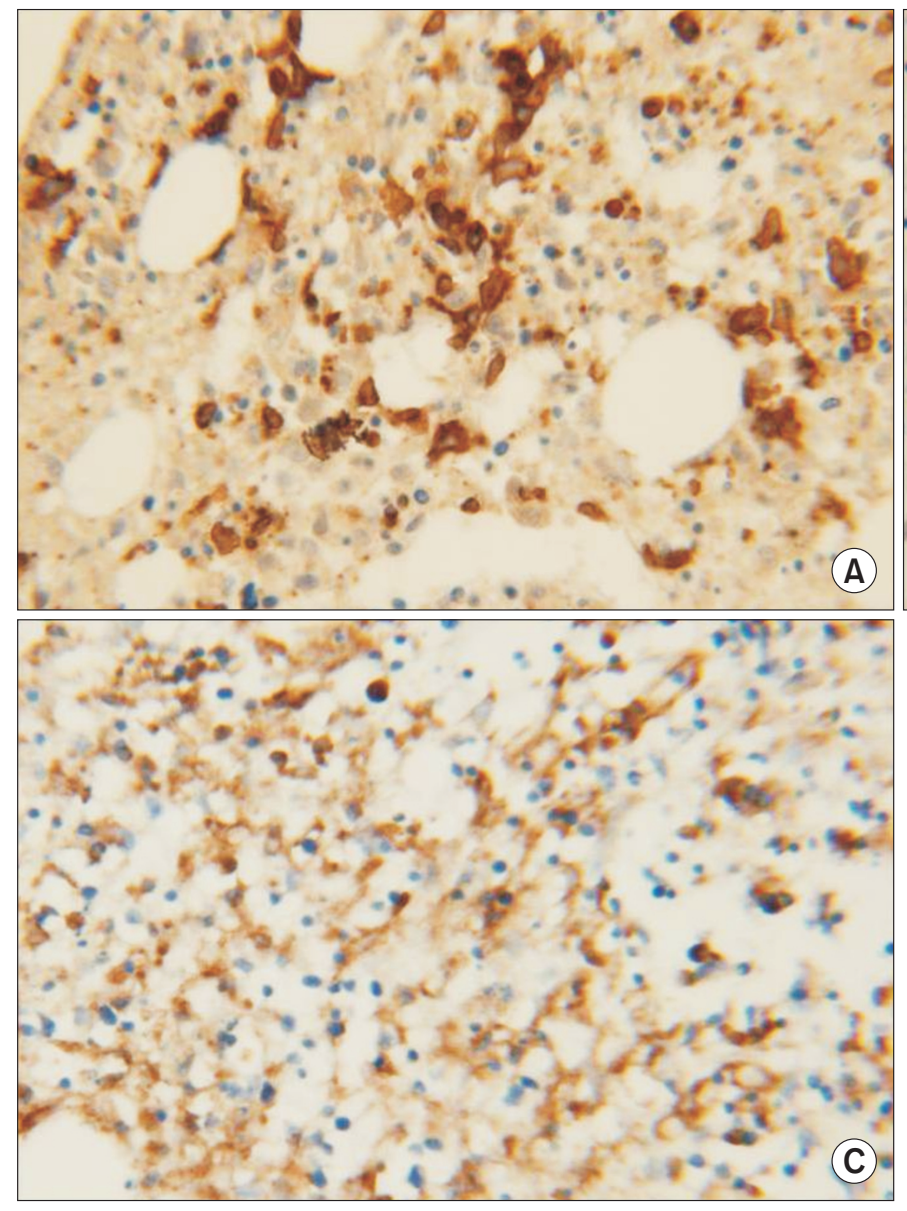

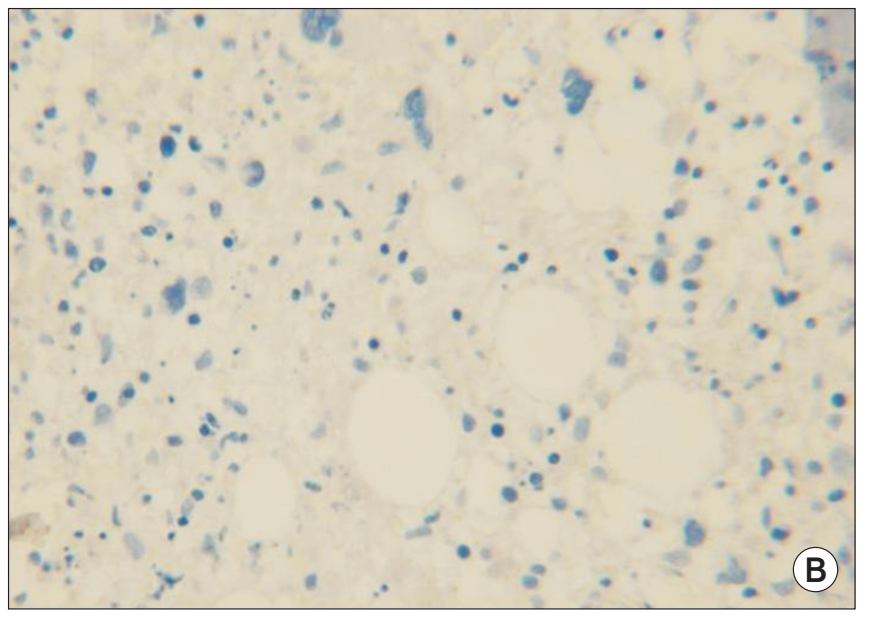

Fig. 2. Immunohistochemical findings in the bone marrow biopsy $(\times 400)$ revealing $(\mathrm{A})$ atypical lymphoid cells showing positive CD3 and (B) negative CD20. (C) Numerous histiocytes expressing CD68. 


\section{Naery Yang et al • Systemic EBV-Positive T-cell Lymphoproliferative Disease of Childhood}

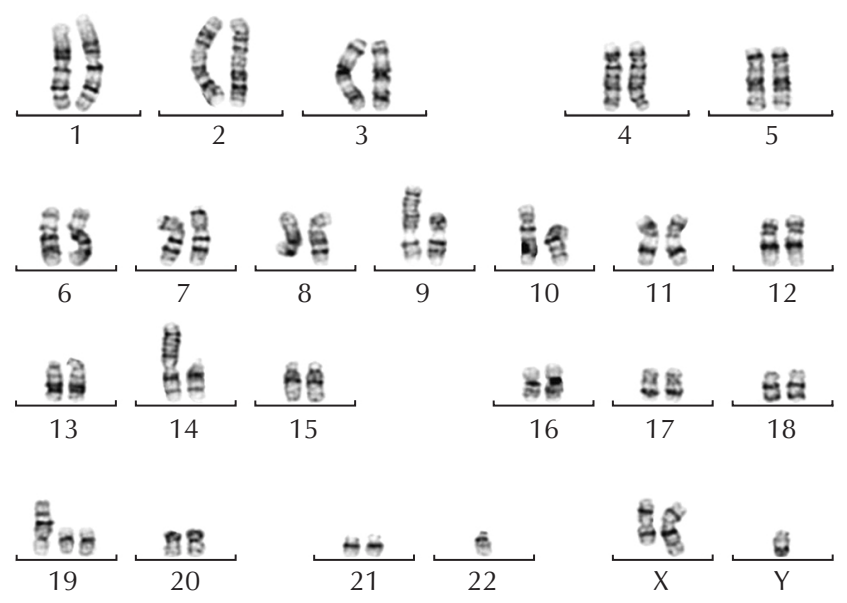

Fig. 3. Chromosome analysis showing complex karyotype of $47, \mathrm{XY},+\operatorname{del}(\mathrm{X})(\mathrm{q} 24)$, ?del(6)(q13q21), $\operatorname{add}(9)(\mathrm{p} 24), \operatorname{add}(14)$ (p10),+19, der(19)t(1;19)(q24;p13.3),-22[cp6]/46,XY[14].

\section{DISCUSSION}

This report describes the case of a patient who initially presented with HLH with complex karyotype. Further investigation revealed systemic EBV $+\mathrm{T}-$ cell LPD of childhood, and the disease rapidly took a fatal clinical course.

EBV+T-cell LPD may be accompanied by HLH, triggered by inflammatory cytokines. A clear distinction between EBV+HLH and systemic EBV+T-cell LPD of childhood is particularly difficult due to the technical limitations of clonality assessment. However, the recognition of systemic EBV + T-cell LPD of childhood within $\mathrm{EBV}+\mathrm{HLH}$ is an important issue, because systemic EBV $+\mathrm{T}-$-cell LPD of childhood should be treated with more intensive chemotherapy and its clinical outcome is different from most EBV + HLH cases which have a favourable prognosis [6]. The clonality of EBVinfected T-cells can be assessed by various methods, including analysis of T-cell receptor gene rearrangement, investigation of the terminal repeats of the EBV genome, and chromosomal analysis. In our patient, clonal T-cell proliferation was demonstrated by the presence of a complex karyotype on chromosomal analysis. Two cases of HLH with chromosomal abnormalities have been reported in Korea [7,8]. In one case, EBV associated HLH with complex karyotype in a 57-year-old man took a fatal course; the patient died on hospital day 28 [7]. The other study described the case of a 75-year-old man with cytomegalovirus infection-associated HLH with complex karyotype who expired on hospital day 13 [8]. Hidden malignancies were not detected in either case. However, both studies suggested that, regardless of presence or absence of a hidden malignancy at initial presentation, it was of great importance to investigate chromosomal abnormalities and consider them as malignant changes $[7,8]$.

The clinical impact of clonality in EBV+T-cell LPD remains to be clarified. Some studies showed that chromosomal abnormalities were associated with an aggressive clinical course $[3,9,10]$, whereas clonality itself had no meaningful clinical impact on the patients' outcome in other studies [10-12].

In a Japanese study on EBV T/NK-cell LPD in non-immunocompromised hosts, chromosomal aberrations were detected in 6 patients out of 91 at diagnosis. Six additional patients later developed chromosomal aberrations during disease progression within 1 to 9 years (median, 5 years) [3]. In this study, the crude mortality rate in the patients with and without chromosomal abnormalities was 75\% and 48\%, respectively [3]. Some patients with EBV+ T-cell LPD who had clonality at early stages subsequently developed overt lymphoma or leukaemia with an increase of chromosomal aberrations over their clinical course [3]. The clonal chromosomal abnormalities associated with poor prognosis were highlighted in many other studies $[6,7,9,12-16]$. In our patient, a complex karyotype was revealed by chromosomal analysis, and the disease rapidly took a fatal course. In conclusion, since systemic EBV+ T-cell LPD of childhood may present as fatal HLH with chromosomal abnormalities and take a very aggressive course, a diagnostic workup of chromosomal analysis is necessary to establish an optimum treatment plan. 


\section{REFERENCES}

1. Cohen JI, Kimura H, Nakamura S, Ko YH, Jaffe ES. Epstein-Barr virus-associated lymphoproliferative disease in non-immunocompromised hosts: a status report and summary of an international meeting, 8-9 September 2008. Ann Oncol 2009;20:1472-82.

2. Lim MS, de Leval L, Quintanilla-Martinez L. Commentary on the $2008 \mathrm{WHO}$ classification of mature T- and NK-cell neoplasms. J Hematop 2009;2:65-73.

3. Kimura H, Ito Y, Kawabe S, Gotoh K, Takahashi Y, Kojima $\mathrm{S}$, et al. EBV-associated T/NK-cell lymphoproliferative diseases in nonimmunocompromised hosts: prospective analysis of 108 cases. Blood 2012;119:673-86.

4. Quintanilla-Martinez L, Kimura H, Jaffe ES. EBV-positive T-cell lymphoproliferative disorders of childhood. In: Swerdlow SH, editor. WHO classification of tumours of haematopoietic and lymphoid tissues. 4th ed. Lyon: International Agency for Research on Cancer, 2008:27880.

5. Henter JI, Horne A, Arico M, Egeler RM, Filipovich AH, Imashuku S, et al. HLH-2004: diagnostic and therapeutic guidelines for hemophagocytic lymphohistiocytosis. Pediatr Blood Cancer 2007;48:124-31.

6. Yoshii M, Ishida M, Hodohara K, Okuno H, Nakanishi R, Yoshida T, et al. Systemic Epstein-Barr virus-positive T-cell lymphoproliferative disease of childhood: report of a case with review of the literature. Oncol Lett 2012;4:381-4.

7. Kim KH, Kim SH, Lee JK, Cho Y, Kim YK, Shin DH, et al. A case of Epstein-Barr virus-associated hemophagocytic lymphohistiocytosis with clonal karyotype abnormality. Korean J Lab Med 2005;25:85-9.

8. Choi GR, Kim HN, Cho CH, Yoo BJ, Kim MH, Kim JS, et al. A case of hemophagocytic lymphohistiocytosis with clonal karyotype abnormalities. Lab Med Online 2011;1:110-4.
9. Ito E, Kitazawa J, Arai K, Otomo H, Endo Y, Imashuku S, et al. Fatal Epstein-Barr virus-associated hemophagocytic lymphohistiocytosis with clonal karyotype abnormality. Int J Hematol 2000;71:263-5.

10. Imashuku S, Hibi S, Tabata Y, Itoh E, Hashida T, Tsunamoto K, et al. Outcome of clonal hemophagocytic lymphohistiocytosis: analysis of 32 cases. Leuk Lymphoma 2000;37:577-84.

11. Ahn JS, Rew SY, Shin MG, Kim HR, Yang DH, Cho D, et al. Clinical significance of clonality and Epstein-Barr virus infection in adult patients with hemophagocytic lymphohistiocytosis. Am J Hematol 2010;85:719-22.

12. Lin MT, Chang HM, Huang CJ, Chen WL, Lin CY, Lin CY, et al. Massive expansion of $\mathrm{EBV}+$ monoclonal $\mathrm{T}$ cells with CD5 down regulation in EBV-associated haemophagocytic lymphohistiocytosis. J Clin Pathol 2007;60:101-3.

13. Ohshima K, Kimura H, Yoshino T, Kim CW, Ko YH, Lee SS, et al. Proposed categorization of pathological states of EBV-associated T/natural killer-cell lymphoproliferative disorder (LPD) in children and young adults: overlap with chronic active EBV infection and infantile fulminant EBV T-LPD. Pathol Int 2008;58:209-17.

14. Ohga S, Ishimura M, Yoshimoto G, Miyamoto T, Takada $\mathrm{H}$, Tanaka $\mathrm{T}$, et al. Clonal origin of Epstein-Barr virus (EBV)-infected T/NK-cell subpopulations in EBVpositive T/NK-cell lymphoproliferative disorders of childhood. J Clin Virol 2011;51:31-7.

15. Chen JS, Tzeng CC, Tsao CJ, Su WC, Chen TY, Jung YC, et al. Clonal karyotype abnormalities in EBV-associated hemophagocytic syndrome. Haematologica 1997;82:572-6.

16. Krishna R, Byrne E, Burbridge J, Salooja N, Naresh KN. The Hammersmith hospital hematopathology case of the month: hemophagocytic lymphohistiocytosis secondary to Epstein-Barr virus associated T-cell lymphoma. Leuk Lymphoma 2011;52:1127-32. 
염색체 이상을 동반한 혈구포식림프조직구증으로 발현한 엡스타인바바이러스양성소아전신성T세포림프증식질환 양내리 ${ }^{1}$ 정화순 ${ }^{1}$ 문영철 ${ }^{2}$ 허정원 ${ }^{1}$

이화여자대학교 의과대학 ${ }^{1}$ 진단검사의학과, ${ }^{2}$ 내과

엡스타인바바이러스양성 $T$ 세포림프증식질환은 $T$ 세포의 클론성 증식을 특징으로 하는데, 이것은 혈 구포식림프조직구증을 일으킬 수도 있다. 혈구포식림프조직구증에서 염색체 이상은 악성 기저질환과 연관되어 있을 수 있다. 저자는 염색체 이상을 동반한 혈구포식림프조직구증으로 발현한 엡스타인바 바이러스양성소아전신성T세포림프증식질환 사례를 보고하고자 한다. 19세의 남자 환자가 2주 동안 열이 나서 병원에 입원하였으며 범혈구감소증, 고중성지방증, 페리틴의 고농도 증가와 간기능 이상

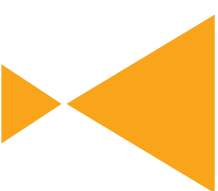

Journal of

LABORATORY MEDICINE and

QUALITY ASSURANCE 이 발견되었다. 혈청학적 검사와 실시간 중합효소연쇄반응을 통해 엡스타인바바이러스 감염이 확인 되었다. 골수검사에서는 조직구 과다증식과 혈구포식증이 관찰되었고, EBV-encoded RNA, CD3, $\mathrm{CD} 4$, 그리고 $\mathrm{CD} 8$ 양성인 비전형적 림프구들이 발견되었다. 염색체검사에서는 복잡핵형이 관찰되었 다. 강력한 치료에도 불구하고 환자는 입원 15일 만에 사망하였다. 결론적으로 혈구포식림프조직구 증과 염색체 이상이 동반된 엡스타인바바이러스양성소아전신성T세포림프증식질환은 빠르게 진행되 며 치명적일 수 있으므로 염색체 이상에 대한 검사가 필수적이다.

(J Lab Med Qual Assur 2014;36:210-215) 